\begin{tabular}{|l|l|l||}
\hline \multicolumn{2}{|c|}{ PublisherInfo } \\
\hline \hline PublisherName & $:$ & BioMed Central \\
\hline \hline PublisherLocation & $:$ & London \\
\hline \hline PublisherImprintName & $:$ & BioMed Central \\
\hline \hline
\end{tabular}

\title{
Mouse mutagenesis
}

\begin{tabular}{|l|l|l||}
\hline \multicolumn{2}{|c|}{ ArticleInfo } \\
\hline \hline ArticleID & $:$ & 4410 \\
\hline \hline ArticleDOI & $:$ & $10.1186 /$ gb-spotlight-20020226-01 \\
\hline \hline ArticleCitationID & $:$ & spotlight-20020226-01 \\
\hline \hline ArticleSequenceNumber & $:$ & 76 \\
\hline \hline ArticleCategory & $:$ & Research news \\
\hline ArticleFirstPage & $:$ & 1 \\
\hline \hline ArticleLastPage & $:$ & 2 \\
\hline \hline & & RegistrationDate : 2002-2-26 \\
\hline ArticleHistory & $:$ & OnlineDate \\
\hline \hline ArticleCopyright & $:$ & BioMed Central Ltd2002-26 \\
\hline \hline ArticleGrants & $:$ & \\
\hline \hline ArticleContext & $:$ & 130593311 \\
\hline \hline
\end{tabular}




\section{Jonathan B Weitzman}

Email: jonathanweitzman@hotmail.com

Large-scale mutagenesis projects using the chemical mutagen ethylnitrosurea (ENU) are being developed to help with the functional annotation of the mouse genome. In an Advanced Online Publication in Nature Genetics, Coghill et al. describe a gene-driven approach to find mutant mice (19 February 2002, DOI:10.1038/ng847). They screened over 2,000 samples contained within an archive of DNA and sperm from the UK ENU mutagenesis program. They screened the archives for four genes using denaturing liquid chromatography and found mutations in three of them. They were able to isolate three mutations (one missense and one stop mutation) within the Gjb2 gene that encodes connexin 26 (which is mutated in cases of human nonsyndromic deafness). They could also recover mutant mice from the frozen sperm archive using in vitro fertilization, and to confirm the embryonic lethality phenotypes arising from an absence of GJB2. Coghill et al. estimate that the ENU-induced mutation rate is around 1 nucleotide change per $2.38 \mathrm{Mb}$ of coding sequence; parallel DNA and sperm archives will facilitate simple screening for point mutations in the mouse genome.

\section{References}

1. A systematic, genome-wide, phenotype-driven mutagenesis programme for gene function studies in the mouse.

2. Nature Genetics, [http://www.nature.com/ng] 